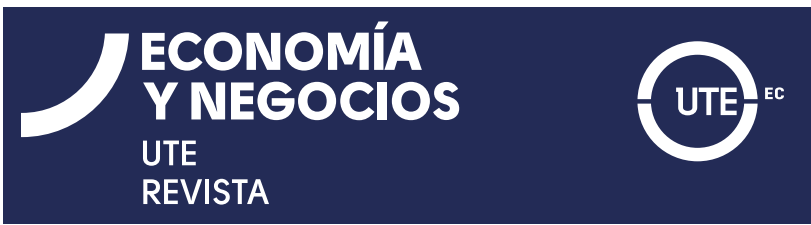

Economía y Negocios, 2021, 12(02), 64-75.

http://revistas.ute.edu.ec/index.php/economia-y-negocios

\section{ARTÍCULO DE INVESTIGACIÓN}

ISSN-e: $2602-8050$

Recibido (Received): 2021/08/06 Aceptado (Accepted): 2021/10/02 Publicado (Published): 2021/12/06

https://doi.org/10.29019/eyn.v12i2.970

\title{
Essential Skills for Ecuadorian Entrepreneur"s Success
}

\section{Habilidades Esenciales para el Éxito del Emprendedor Ecuatoriano}

\section{Gelmar GARCÍA-VIDAL' (iD y Laritza GUZMÁN-VILAR ${ }^{2}$ iD}

1. Universidad UTE, Facultad de Ciencias Administrativas. Santo Domingo, Ecuador.

2. Universidad UTE, Facultad de Derecho y Ciencias Sociales. Santo Domingo, Ecuador.

Email: gelmar.garcia@ute.edu.ec; laritza.guzman@ute.edu.ec

\begin{abstract}
This article presents a study that determines the skills considered essential for entrepreneurs from a theoretical and practical point of view.

For the development of this research, two phases were developed, the first was oriented to the analysis of the existing agreement between Ecuadorian entrepreneurs on the skills that, according to the analyzed literature, contribute to the success of a business; and the second to verify the agreement in the results obtained and validate the skills identified. The study involved 10 experts and 400 entrepreneurs, considered successful, to identify what they considered to be essential skills for the success of a venture based on skills recognized in the literature.

The results made it possible to consistently identify the essential entrepreneurial skills in the Ecuadorian context with high statistical significance, which leads to suggest that these skills should be enhanced in the training of incipient entrepreneurs already consolidated in the market. Through the research, it was conclusively revealed that the entrepreneurs studied consider that these skills are facilitators of the success of their businesses, so their mastery could contribute to reduce the mortality rate of both new and established businesses.
\end{abstract}

\section{Keywords}

Entrepreneurships, entrepreneurial skills, business success.

\section{Resumen}

Este artículo presenta un estudio que determina las habilidades que se consideran esenciales para los emprendedores desde un punto de vista teórico y práctico

Para esta investigación se desarrollaron dos fases. La primera se orientó al análisis del acuerdo existente entre emprendedores ecuatorianos sobre las habilidades que, según la literatura analizada, contribuyen al éxito de un negocio. En la segunda fase se verificó la concordancia de los resultados obtenidos y se validaron las habilidades identificadas. El estudio involucró a 10 expertos y 400 emprendedores considerados exitosos, para identificar lo que consideraron habilidades esenciales para el éxito de un emprendimiento.

Los resultados permitieron identificar consistentemente las habilidades emprendedoras esenciales en el contexto ecuatoriano con alta significación estadistica, lo que lleva a plantear que estas habilidades deben potenciarse en la formación de emprendedores incipientes ya consolidados en el mercado. Por medio de la investigación se reveló de manera concluyente que los emprendedores estudiados consideran que estas habilidades son facilitadores del éxito de sus negocios, por lo que su dominio podría contribuir a reducir la tasa de mortalidad tanto de los negocios nuevos como de los ya consolidados.

\section{Palabras clave}

Emprendimiento, habilidades para el emprendimiento, éxito empresarial.

Códigos de clasificación JEL: M12, M14, L26. 


\section{Introduction}

Previous studies on entrepreneurship have focused on the entrepreneurial skills necessary to guarantee business success (Ataei et al., 2020; Din et al., 2016; Hatthakijphong \& Ting, 2019; Kyndt \& Baert, 2015; Morgan et al., 2010; Schelfhout et al., 2016; Seuneke et al., 2013; Strauti et al., 2018; Usman \& Tasmin, 2015). For this study, previous studies are taken into account and the levels of sales of the ventures will be assumed as success criteria (Gorgievski et al., 2011; Hatthakijphong \& Ting, 2019; Read et al., 2017).

As far as is known, there are no previous studies in the Ecuadorian context that take into account the perception of entrepreneurs on those aspects that are considered essential for the good performance of their ventures. This aspect is essential if one takes into account that, although the progress is significant in terms of entrepreneurship training since it has doubled in just one generation, it is estimated that among young people, two thirds have not received this type of training (Lasio et al., 2018; Zambrano \& Lasio, 2019). On this subject, Zambrano \& Lasio (2019, p. 17) state that "higher education institutions are showing greater interest in integrating entrepreneurship in their curricular networks. However, although improvements are perceived in basic education levels, it is considered that creativity, self-sufficiency and personal initiative can be further stimulated in the classrooms".

In Ecuador it is observed that entrepreneurs are mostly people whose highest educational level is primary or secondary where; Despite receiving training on entrepreneurship, skills are not enough to lead a small business to success (Zambrano \& Lasio, 2019); "Hence the importance of education and in particular of entrepreneurship education, which is still a weakness in basic education levels, although it predominates in higher education" (Zambrano \& Lasio, 2019, p. 32). In general, it is possible to say that Ecuador exhibits a very low or no level of education, both in senior entrepreneurs (45\%) and in older ones (56\%), with rates much higher than those of other countries in the region (Lasio et al., 2018).

The complexity of entrepreneurship systems requires the development of entrepreneurs with specific capacities and competencies, to promote the success of their businesses (Ataei et al., 2020; Bustamante \& Cabrera, 2017; Ismail et al., 2015). It should be noted that this positive performance is of vital importance, since in general, enterprises make an important contribution to the sustainable economic development of a nation, through their contribution to GDP and the reduction of unemployment (Ataei et al., 2020; Din et al., 2016; Read et al., 2017; Schelfhout et al., 2016; Zamora-Boza, 2018).

Entrepreneurial skills are related to the ability to do something and are recognized as relatively easy to learn and change in a short term to favor the development of the administrative process of an enterprise (Ataei et al., 2020; Ismail et al., 2015; Kyndt $\&$ Baert, 2015). Some authors affirm that entrepreneurial skills are directly related to administrative skills (Kyndt \& Baert, 2015).

This article aims to present the skills perceived as distinctive of Ecuadorian entrepreneurs who work in micro and small companies. This research is relevant for those interested because it facilitates the orientation to the training processes of current entrepreneurs, future entrepreneurs and the adjustment, as far as possible, of university degree programs to introduce subjects that allow the development of skills they need to achieve a successful venture. The aforementioned would allow reinforcing education in entrepreneurship and thus contribute to improving the entrepreneurial skills of the general population (Bustamante \& Cabrera, 
2017; Sanchez i Peris \& Ros Ros, 2014; Zambrano \& Lasio, 2019; Zamora-Boza, 2018).

\section{Materials and methods}

For the development of this research, two research phases were developed. The first was oriented to the analysis of the existing agreement between Ecuadorian entrepreneurs regarding the skills that, according to the analyzed literature, contribute to the success of a business. For these purposes, a focus group is developed, the participating entrepreneurs are asked to order from 1 to 10 the skills identified in the literature to obtain a consensus regarding descending pre- ferences according to their perception of the importance for the success of a business.

With these ordinal data, the consensus method is applied (Borgatti, 1994; Horowitz, 2009; Lacy et a., 2018), which begins with a response matrix $n$ per $m$ person, in which cell xij gives the response of person i to skill $j$. Each skill has exactly $L$ possible responses that are numbered from 1 to 10 . The analysis begins by constructing a "person by person" agreement matrix $M$, in which $m^{*} i j$ is equal to the number of skills for which people I and J they give exactly the same answers. The aforementioned can be expressed in the following equation (Borgatti, 1994):

$$
\text { Equation 1: } m_{i j}^{*}=\frac{\left(L m_{i j}-1\right)}{(L-1)}
$$

For the development of the consensus method, UCINET 6.629 for Windows (Borgatti et al., 2002) will be used. Once the results of the agreement have been obtained, a survey will be applied, which will use an importance scale with the following categories of responses: very important (5), important (4), neutral (3), not important (2) and no importance at all (1) (Malhotra, 2008). These items will evaluate the importance of the skills that obtain consensus among the experts based on their contribution to the business success of the surveyed entrepreneurs.

To determine the discriminatory power, the mean scores of the $25 \%$ of the entrepreneurs who obtained a higher score and the $25 \%$ of those who scored the lowest are computed. The analysis of these differences will be carried out with the Mann-Whitney $U$ test relevant for this situation in which it is desired to check the heterogeneity of two independent samples involving ordinal variables. The hypothesis is stated as follows:
$\mathrm{H}_{0}: \bar{x}_{25 \% \text { higher }}=\bar{x}_{25 \% \text { lower }}$. There will be no statistically significant differences between the group mean.

$H_{1}: \bar{x}_{25 \% \text { higher }}{ }^{1} \bar{x}_{25 \% \text { lower }}$. There will be statistically significant differences between the group mean.

Next, the difference between the two means of the ratings given to each skill by both groups is taken to determine the discriminatory power. Skills whose difference between the two means is less than 1 are rejected, as they do not discriminate enough between entrepreneurs with high and low qualifications, while skills whose mean difference is equal to or greater than 1 are accepted. Finally, the coefficient of ambiguity to know if there is agreement in the scores given to skills in analysis. This coefficient is found in the difference between means for each skill between the third quartile and the first, if it is greater than 2 in any of the skills studied, it implies that, since there is no agreement, it should not be taken into account as essential skill for the success of an enterprise. 


\section{Characterization of the sample used}

To identify the entrepreneurs to study, the database made available to users by the $\mathrm{Na}$ tional Institute of Statistics and Censuses (National Institute of Statistics and Censuses of Ecuador [INEC], 2018) with the results of the Structural Business Survey (ENESEM), corresponding to the year 2017 (INEC, 2019). The focus group is developed with 10 entrepreneurs selected according to the judgment of the province of Santo Domingo de los Tsáchilas, a practical scope of application. The trial responded to the experience in years as an entrepreneur in micro and small companies and demonstrated success in the business taking into account years in the market and sales levels. The average experience as an entrepreneur is 25 years, in the current business the average in years of operation is 11.3 and the sales of the businesses are above the third quartile $\$ 290,765.00$.

To apply the survey, we worked with the database by analyzing the data and leaving only those companies that had the completeness of the variables that they wanted to know (province, size, sector of the economy, sales). After working with the database, a total of 18,732 micro and small businesses were obtained in Santo Domingo de los Tsáchilas, which will be assumed as the population to be studied (Table 1).

Table 1. Population to study

\begin{tabular}{|c|c|c|c|c|c|c|c|}
\hline \multirow[b]{2}{*}{ Size of enterprises } & \multicolumn{6}{|c|}{ Economic sectors } & \multirow[b]{2}{*}{ Total } \\
\hline & 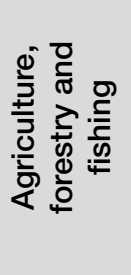 & 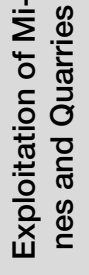 & 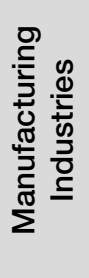 & 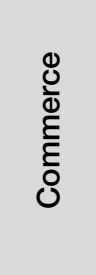 & 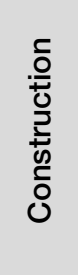 & 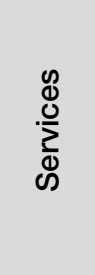 & \\
\hline Micro-enterprise & 728 & 16 & 354 & 2486 & 393 & 3494 & 7471 \\
\hline Percentage (\%) & 9.7 & 0.2 & 4.7 & 33.3 & 5.3 & 46.8 & 100.0 \\
\hline Small enterprise & 1425 & 7 & 776 & 6030 & 433 & 2590 & 11261 \\
\hline Percentage (\%) & 12.7 & 0.1 & 6.9 & 53.5 & 3.8 & 23.0 & 100.0 \\
\hline Total & 2153 & 23 & 1130 & 8516 & 826 & 6084 & 18732 \\
\hline
\end{tabular}

With these data a proportional stratified random sampling is developed. First, the two strata of interest are determined: microenterprise $(7,471)$ and small company $(11,261)$, with a $95.45 \%$ confidence, a $5 \%$ allowed error as a researcher and assuming $p=q=50 \%$, obtained a total sample size of 400 entrepreneurs (160 micro entrepreneurs and 240 small entrepreneurs). It was also considered interesting to take into ac- count the sector of the economy in which the entrepreneurs develop to achieve a greater representativeness of the final sample, so within each stratum the proportions that the sectors of the economy represent in the population analyzed are analyzed in order to calculate its proportion in each stratum. Final results of the sample are shown in Table 2. 
Table 2. Final results of the sample

\begin{tabular}{|c|c|c|c|c|c|c|c|}
\hline \multirow[b]{2}{*}{ Size of enterprises } & \multicolumn{6}{|c|}{ Economic sectors } & \multirow[b]{2}{*}{ Total } \\
\hline & 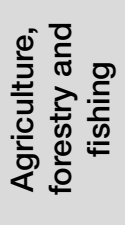 & 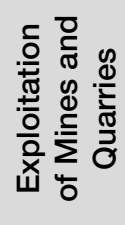 & 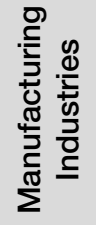 & 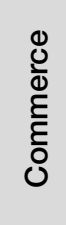 & $\begin{array}{l}\frac{c}{0} \\
\frac{0}{0} \\
0 \\
\frac{2}{ \pm} \\
0 \\
0 \\
0 \\
0\end{array}$ & $\begin{array}{l}\mathscr{d} \\
\stackrel{0}{\infty} \\
\stackrel{\infty}{\infty}\end{array}$ & \\
\hline Micro-enterprise & 16 & 1 & 7 & 53 & 8 & 75 & 160 \\
\hline Small enterprise & 30 & 1 & 17 & 128 & 9 & 55 & 240 \\
\hline Total & 46 & 2 & 24 & 181 & 17 & 130 & 400 \\
\hline
\end{tabular}

Finally, the sample was characterized from the aspects shown in table 3 . Following the logic of this research, the businesses that make up the sample are considered suc- cessful since they have obtained sales above the average in their category according to company size; $\$ 40,069.00$ for micro-enterprise and $\$ 320,927.63$ for small enterprises.

Table 3. Characteristics of the sample

\begin{tabular}{|c|c|c|c|c|c|c|c|c|c|c|}
\hline & \multicolumn{2}{|c|}{ Sex } & \multicolumn{4}{|c|}{ Opening years } & \multicolumn{4}{|c|}{ Education } \\
\hline $\begin{array}{c}\text { Size of } \\
\text { enterprises }\end{array}$ & $\frac{0}{\sum}$ & 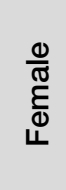 & 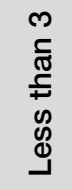 & 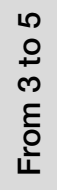 & $\begin{array}{l}\infty \\
0 \\
0\end{array}$ & 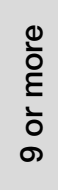 & 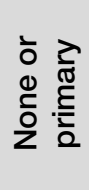 & 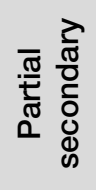 & 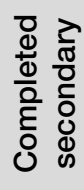 & 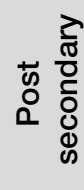 \\
\hline Micro-enterprise & 86 & 74 & 107 & 10 & 13 & 30 & 88 & 11 & 32 & 29 \\
\hline Small enterprise & 130 & 110 & 160 & 16 & 19 & 45 & 132 & 17 & 48 & 43 \\
\hline Total & 216 & 184 & 267 & 26 & 32 & 75 & 220 & 28 & 80 & 72 \\
\hline
\end{tabular}

\section{Analysis and results}

The first phase of the research was developed through a focus group session with the 10 entrepreneurs considered successful. The results of the perceptions of the skills that are considered essential for the success of an enterprise are shown in table 4.

With the result of the focus group session, the consensus analysis method was applied. Table 5 provides results of the execution of the method on the data obtained.

Table 6 indicates a good fit with the consensus model by showing the absence of negative proficiency scores and a high ratio between the largest eigenvalue to the second largest (3.656). The eigenvalue pattern is highly consistent with the assumption of a unique set of correct answers and conditional independence. The high proportion of the first and second eigenvalues allows us to interpret the loads of factors such as the competence scores of each entrepreneur in the analysis of the essential skills for the success of an enterprise. Table 6 indicates that entrepreneurs E4 and E10 have the highest competition within the group of participating entrepreneurs. 
Table 4. Results of the perceptions of the participating entrepreneurs*

\begin{tabular}{|c|c|c|c|c|c|c|c|c|c|c|}
\hline & 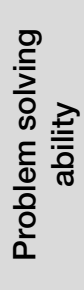 & 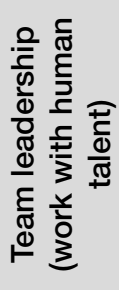 & 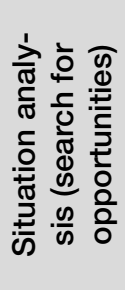 & 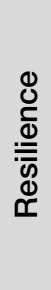 & 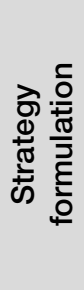 & 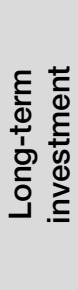 & 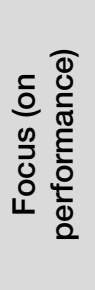 & 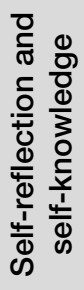 & 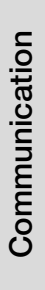 & 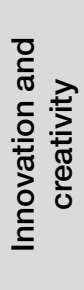 \\
\hline E1 & 1 & 2 & 4 & 10 & 8 & 5 & 6 & 9 & 7 & 2 \\
\hline E2 & 2 & 1 & 4 & 10 & 6 & 8 & 5 & 3 & 7 & 9 \\
\hline E3 & 2 & 1 & 3 & 7 & 4 & 8 & 10 & 6 & 5 & 9 \\
\hline E4 & 1 & 1 & 3 & 9 & 5 & 8 & 5 & 5 & 8 & 10 \\
\hline E5 & 2 & 1 & 8 & 10 & 3 & 6 & 7 & 9 & 4 & 5 \\
\hline E6 & 2 & 1 & 8 & 10 & 3 & 6 & 7 & 9 & 4 & 5 \\
\hline E7 & 1 & 2 & 4 & 10 & 8 & 5 & 6 & 9 & 7 & 2 \\
\hline E8 & 2 & 1 & 4 & 10 & 6 & 8 & 5 & 3 & 7 & 9 \\
\hline E9 & 2 & 1 & 3 & 7 & 4 & 8 & 10 & 6 & 5 & 9 \\
\hline E10 & 1 & 1 & 3 & 9 & 5 & 8 & 5 & 5 & 8 & 10 \\
\hline
\end{tabular}

Note: * Some entrepreneurs decided to assign the same order to more than one skill. These linked assignments are assigned the average of the ranks that would have been assigned if these links had not occurred.

Table 5. Goodness of fit of the consensus model

\begin{tabular}{|l|c|}
\hline \multicolumn{1}{|c|}{ Number of negative competencies: } & 0 \\
\hline Largest eigenvalue: & 6.243 \\
\hline 2nd largest eigenvalue: & 1.707 \\
\hline Ratio of largest to next: & 3.656 \\
\hline
\end{tabular}

If you are interested in learning more about entrepreneurial skills, entrepreneurs E4 and E10 could be a good source of additional information. It is interesting to note that the E4 entrepreneur is a person over 15 years old with an established business with vast experience in previous ventures and the E10 entrepreneur is a young entrepreneur with a university preparation. The presence of entrepreneurs who would have provided responses very different from the cultural norm would have negative proficiency scores in this table. The above is one more manifestation of the consensus among the entrepreneurs participating in the focus group. Finally, the consensus model also identifies the culturally correct importance of each skill, as shown in table 7. 
Table 6. Entrepreneurs' competence score

\begin{tabular}{|c|c|c|}
\hline Order & Entrepreneurs & Competence \\
\hline 1 & E4 & 0.921 \\
\hline 2 & E10 & 0.921 \\
\hline 3 & E8 & 0.882 \\
\hline 4 & E2 & 0.882 \\
\hline 5 & E9 & 0.822 \\
\hline 6 & E3 & 0.822 \\
\hline 7 & E6 & 0.681 \\
\hline 8 & E5 & 0.681 \\
\hline 9 & E7 & 0.597 \\
\hline 10 & E1 & 0.597 \\
\hline
\end{tabular}

Table 7. Importance of the skills studied

\begin{tabular}{|l|l|c|}
\hline \multicolumn{1}{|c|}{ Order } & \multicolumn{1}{|c|}{ Skills } & Ranking \\
\hline 1 & Team leadership (work with human talent) & 1.15 \\
\hline 2 & Problem solving ability & 1.61 \\
\hline 3 & Situation analysis (search for opportunities) & 4.25 \\
\hline 4 & Strategy formulation & 5.13 \\
\hline 5 & Self-reflection and self-knowledge & 6.07 \\
\hline 6 & Communication & 6.29 \\
\hline 7 & Focus (on performance) & 6.55 \\
\hline 8 & Long-term investment & 7.19 \\
\hline 9 & Innovation and creativity & 7.47 \\
\hline 10 & Resilience & 9.13 \\
\hline
\end{tabular}

The result provides an importance for each skill and allows to easily differentiate the most essential skills from the less essential ones according to the opinion of the participants. However, what is sought in this phase of the investigation is to obtain an agreement on whether it is possible to work with these skills to continue with the second investigation phase. As a culmination, the consensus analysis results in a network of links based on all the points of view of the participating entrepreneurs (see figure 1).

As the agreement is demonstrated, the survey is applied to obtain the final results of the investigation. 
Figure 1. "True" network of perceived executive relationships derived from consensus

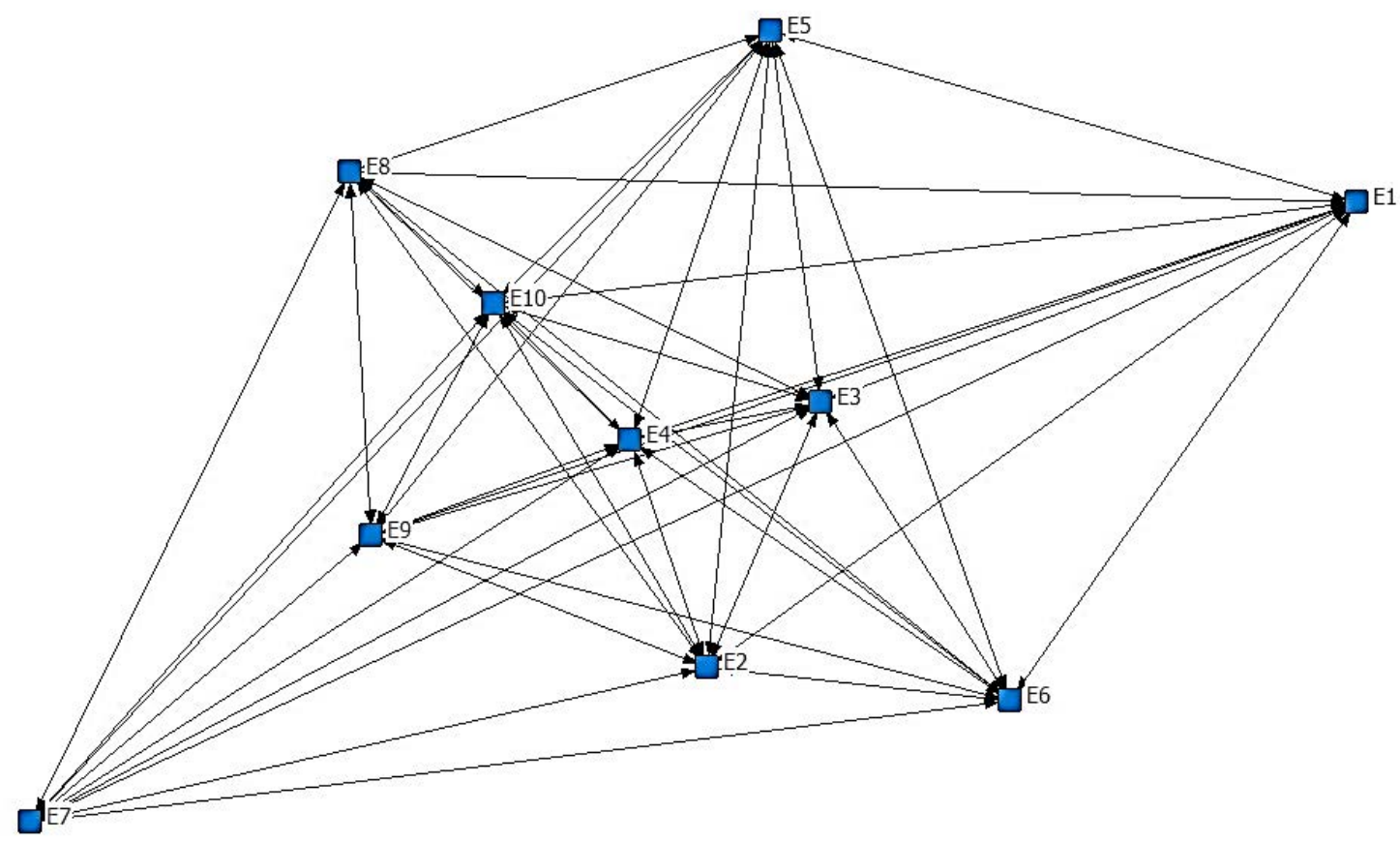

\section{Resulting skills}

The first analysis after the application of the information collection instrument was the verification of the reliability of the collected data. The calculated Cronbach's Alpha was 0.749 , therefore the data is considered relia- ble. With this premise fulfilled, the discriminatory power is determined. Table 8 shows the number of respondents who belong to the lowest $25 \%$ and the highest $25 \%$ of the sums of scores awarded to the skills analyzed.

Table 8. Size of the lowest and highest $25 \%$

\begin{tabular}{|l|c|c|}
\hline & Frequency & Percentage \\
\hline First 25\% & 109 & 27.3 \\
\hline Second 25\% & 95 & 23.8 \\
\hline Third 25\% & 115 & 28.7 \\
\hline Fourth 25\% & 81 & 20.3 \\
\hline Total & 400 & 100.0 \\
\hline
\end{tabular}

Knowing this element, the means obtained for each skill analyzed are calculated for each 25\% that is interesting; This makes it possible to calculate the discriminatory power of the skills studied by means of the significant differences between both groups and to find those essential skills for the success of the ventures, according to the perception of the respondents. The result obtained is the statistical significance of the differences between the means of the entrepreneurs in each group (Figure 2). 
The test indicates that the distributions were compared and that it is possible to reject the null hypothesis of equal distributions. The bar graph shows the distributions and the mean ranges of the two groups. This first result shows the power of discrimination between both groups in general. Now it is necessary to compare the means obtained for each skill in particular, for these purposes the test is repeated (Figure 3).

Figure 2. Result of the Mann-Whitney $U$ test between groups

Hypothesis Test Summary

\begin{tabular}{|llll|}
\hline \multicolumn{1}{|c|}{ Null Hypothesis } & \multicolumn{1}{c|}{ Test } & Sig. & Decision \\
\hline & $\begin{array}{l}\text { Independent- } \\
\text { The distribution of media is the } \\
\text { same across categories of } \\
\text { ubicación. }\end{array}$ & $\begin{array}{l}\text { Samples } \\
\text { Mann- } \\
\text { Whitney U } \\
\text { Test }\end{array}$ & $000 \begin{array}{l}\text { Reject the } \\
\text { null } \\
\text { hypothesis. }\end{array}$ \\
\hline
\end{tabular}

Asymptotic significances are displayed. The significance level is, 05 .

Independent-Samples Mann-Whitney U Test ubicación

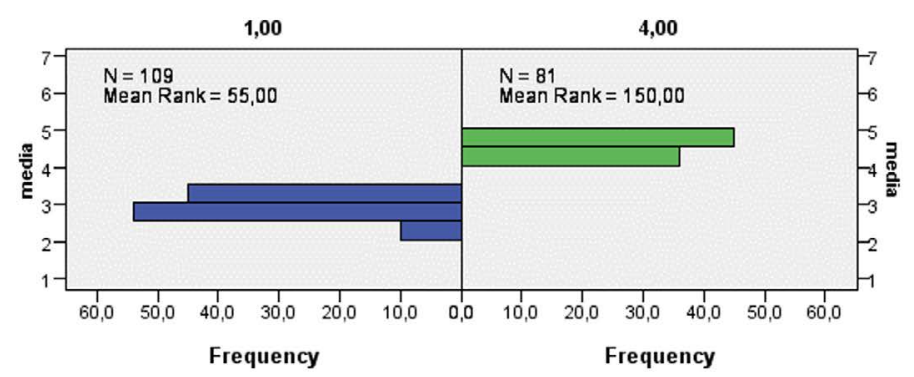

\begin{tabular}{|lr|}
\hline Total N & 190 \\
\hline Mann-Whitney U & $8.829,000$ \\
\hline Wilcoxon W & $12.150,000$ \\
\hline Test Statistic & $8.829,000$ \\
\hline Standard Error & 373,954 \\
\hline Standardized Test Statistic & 11,805 \\
\hline Asymptotic Sig. (2-sided test) &, 000 \\
\hline
\end{tabular}

Figure 3. Result of the Mann-Whitney U test for skills in particular

Hypothesis Test Summary

\begin{tabular}{|c|c|c|c|c|}
\hline & Null Hypothesis & Test & Sig. & Decision \\
\hline 1 & $\begin{array}{l}\text { The distribution of medias is the } \\
\text { same across categories of Grupo. }\end{array}$ & $\begin{array}{l}\text { Independent- } \\
\text { Samples } \\
\text { Mann- } \\
\text { Whitney U } \\
\text { Test }\end{array}$ &, $000^{1}$ & $\begin{array}{l}\text { Reject the } \\
\text { null } \\
\text { hypothesis }\end{array}$ \\
\hline
\end{tabular}

Asymptotic significances are displayed. The significance level is , 05 .

${ }^{1}$ Exact significance is displayed for this test.

Independent-Samples Mann-Whitney U Test Grupo

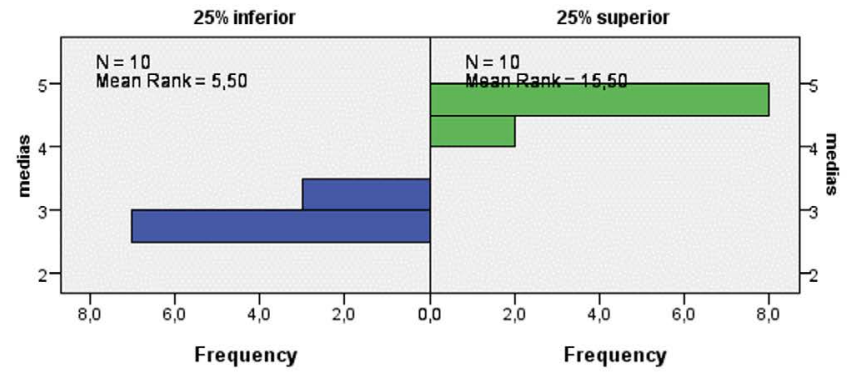

\begin{tabular}{|lr|}
\hline Total N & 20 \\
\hline Mann-Whitney U & 100,000 \\
\hline Wilcoxon W & 155,000 \\
\hline Test Statistic & 100,000 \\
\hline Standard Error & 13,199 \\
\hline Standardized Test Statistic & 3,788 \\
\hline Asymptotic Sig. (2-sided test) &, 000 \\
\hline Exact Sig. (2-sided test) &, 000 \\
\hline
\end{tabular}


As it is possible to appreciate again, the null hypothesis is rejected in a highly significant way, so it can be said that there are significantly different means for each skill depending on the groups analyzed. To appreciate the behavior of the aforementioned more precisely, table 9 is shown.

Table 9. Discriminatory power of means of skills by group

\begin{tabular}{|l|c|c|c|}
\hline \multirow{2}{*}{ Skills } & \multicolumn{2}{|c|}{ Average score per group } & $\begin{array}{c}\text { Difference of means } \\
\text { (Discriminatory } \\
\text { Power) }\end{array}$ \\
\cline { 2 - 3 } & $\mathbf{2 5 \% \text { higher }}$ & $\mathbf{2 5 \% \text { lower }}$ & 1.69 \\
\hline Problem solving ability & 4.62 & 2.93 & 1.90 \\
\hline Team leadership (work with human talent) & 4.69 & 2.79 & 1.46 \\
\hline Situation analysis (search for opportunities) & 4.63 & 3.17 & 1.78 \\
\hline Resilience & 4.72 & 2.94 & 1.06 \\
\hline Strategy formulation & 4.33 & 3.28 & 1.65 \\
\hline Long-term investment & 4.47 & 2.82 & 1.86 \\
\hline Focus (on performance) & 4.54 & 2.69 & 1.90 \\
\hline Self-reflection and self-knowledge & 4.69 & 2.79 & 1.46 \\
\hline Communication & 4.63 & 3.17 & 1.78 \\
\hline Innovation and creativity & 4.72 & 2.94 & \\
\hline
\end{tabular}

Table 9 shows the calculation of the means obtained for each skill analyzed for each $25 \%$ determined, this allows calculating the discriminating power of the skills studied by means of the significant differences between both groups and finding those essential skills for the success of the ventures, according to the perception of the respondents. As the difference between the mean in all cases is greater than 1 , it is possible to say that the discriminatory power is high and that these skills are considered essential to achieve success in the context of Ecuadorian entrepreneurs.

In order to verify the agreement in the results obtained and to validate that these are the essential skills for the success of the ventures, the coefficient of ambiguity was calculated, which is nothing more than the difference between means for each skill between the third quartile and the first. The results are shown in table 10.

Table 10. Coefficient of ambiguity

\begin{tabular}{|l|c|c|c|}
\hline \multirow{2}{*}{\multicolumn{1}{|c|}{ Skills }} & \multicolumn{2}{c|}{ Average score per group } & \multirow{2}{*}{$\begin{array}{c}\text { Difference of means } \\
\text { (Discriminatory power) }\end{array}$} \\
\cline { 2 - 3 } & Quartile 3 & Quartile 1 & 1.15 \\
\hline Problem solving ability & 4.08 & 2.93 & 1.08 \\
\hline Team leadership & 3.87 & 2.79 & 1.01 \\
\hline Situation analysis & 4.18 & 3.17 & 1.08 \\
\hline Resilience & 4.02 & 2.94 & 0.57 \\
\hline Strategy formulation & 3.85 & 3.28 & 1.01 \\
\hline Long-term investment & 3.83 & 2.82 & 1.23 \\
\hline Focus (on performance) & 3.92 & 2.69 & 1.08 \\
\hline Self-reflection and self-knowledge & 3.87 & 2.79 & 1.01 \\
\hline Communication & 4.18 & 3.17 & 1.08 \\
\hline Innovation and creativity & 4.02 & 2.94 & \\
\hline
\end{tabular}


As in none of the cases the value obtained is greater than two, the agreement between the study participants is confirmed.

\section{Discussion and conclusions}

In studies carried out in the Ecuadorian context in relation to the ability to undertake, "experts highlight limitations such as: little global vision, ignorance of the market, ignorance of technical and legal aspects, and weaknesses in the management of new businesses that limit growth and sustainability over time" (Lasio et al., 2018, p. 23).

Ecuadorian entrepreneurs have been questioned by experts in a general way regarding complementary management skills, skills that go beyond the innate capabilities of the entrepreneur (Lasio et al., 2018) and that could be achieved in practice if there is training that helps to have this knowledge.

It is interesting that the predominant actions of nascent entrepreneurs include: defining the business idea (16\%), organizing the work team (13\%), and working on a business plan (11\%) (Lasio et al., 2018); Therefo$r e$, the essential skills identified in this study can be of great help in this phase of the entrepreneurship cycle.

Contributing to the formation of the skills identified and considered essential for the success of ventures would be of great help in creating employment in Ecuador, if one takes into account that " $53.2 \%$ of those who consider themselves capable and are not currently undertaking start a business in the next three years; compared to $35.9 \%$ of those who do not perceive they have the skills to undertake" (Lasio et al., 2018, p. 28).

The results of this study allow us to reach the general conclusion that the identified skills should be enhanced in the training of nascent entrepreneurs and those already consolidated in the market. The research carried out has conclusively revealed that the entrepreneurs studied consider that these skills are facilitators of the success of their businesses, so mastering them could contribute to reducing the mortality rate of nascent and already consolidated enterprises.

It is necessary to make it clear that the identified skills are not immovable, they will have to change over time adjusting to the new conditions (Kyndt \& Baert, 2015), but for the context of this research it allows a clear vision of where to direct the training work with the entrepreneurs.

Finally, it is desired to point out a fundamental limitation of this research and that is that it was developed in only one province of Ecuador, so these results could diverge from one territory to another, thus leaving an open gap for future research related to this topic.

\section{References}

Ataei, P., Karimi, H., Ghadermarzi, H., \& Norouzi, A. (2020). A conceptual model of entrepreneurial competencies and their impacts on rural youth's intention to launch SMEs. Journal of Rural Studies, 75, 185-195. https://doi.org/10.1016/j.jrurstud.2020.01.023

Borgatti, S. P. (1994). Cultural domain analysis. Journal of Quantitative Anthropology, 4, 261-278. https://bit.ly/3BR4C11

Borgatti, S. P., Everett, M. G., \& Freeman, L. C. (2002). Ucinet for Windows: Software for social network analysis. Analytic Technologies. https://bit.ly/2Yp9ywJ

Bustamante, K. P., \& Cabrera, K. S. (2017). Microcrédito, microempresa y educación en Ecuador: Caso de estudio. Cantón Zamora. Espacios, 38(53), 25. https://bit.ly/3oj3z5w

Din, B. H., Anuar, A. R., \& Usman, M. (2016). The effectiveness of the entrepreneurship education program in upgrading entrepreneurial skills among public university students. Procedia: Social and Behavioral Sciences, 224, 117-123. https://doi. org/10.1016/j.sbspro.2016.05.413 
Gorgievski, M. J., Ascalon, M. E., \& Stephan, U. (2011). Small business owners' success criteria: A values approach to personal differences. Journal of Small Business Management, 49(2), 207-232. https://doi. org/10.1111/j.1540-627X.2011.00322.x

Hatthakijphong, P., \& Ting, H. -ı. (2019). Prioritizing successful entrepreneurial skills: An emphasis on the perspectives of entrepreneurs versus aspiring entrepreneurs. Thinking Skills and Creativity, 34, 100603. https://doi.org/10.1016/j.tsc.2019.100603

Horowitz, D. M. (2009). A review of consensus analysis methods in consumer culture, organizational culture and national culture research. Consumption Markets \& Culture, 12(1), 47-64. https://doi. org/10.1080/10253860802560839

Instituto Nacional de Estadística y Censos de Ecuador (INEC). (2018). Tecnologías de la información y comunicación: Encuesta multipropósito-TIC 2018. INEC. https://bit. ly/3B4wXkz

Instituto Nacional de Estadística y Censos de Ecuador (INEC). (2019). Encuestas a empresas. INEC. https://bit.ly/3E1MqUa

Ismail, V. Y., Zain, E., \& Zulihar. (2015). The portrait of entrepreneurial competence on student entrepreneurs. Procedia: Social and Behavioral Sciences, 169, 178-188. https://doi. org/10.1016/j.sbspro.2015.01.300

Kyndt, E., \& Baert, H. (2015). Entrepreneurial competencies: Assessment and predictive value for entrepreneurship. Journal of Vocational Behavior, 90, 13-25. https://doi. org/10.1016/j.jvb.2015.07.002

Lacy, M. G., Snodgrass, J. G., Meyer, M. C., Dengah, H. J. F., \& Benedict, N. (2018). A formal method for detecting and describing cultural complexity: Extending classical consensus analysis. Field Methods, 30(3), 241-257. https://doi.org/10.1177/1525822X18781756

Lasio, V., Ordeñana, X., Caicedo, G., Samaniego, A., \& Izquierdo, E. (2018). Global Entrepreneurship Monitor: Ecuador 2017. ESPAE; ESPOL. https://bit.ly/3ESf3nd
Malhotra, N. K. (2008). Investigación de mercados (5. ${ }^{a}$ Ed). Pearson Educación.

Morgan, S. L., Marsden, T., Miele, M., \& Morley, A. (2010). Agricultural multifunctionality and farmers' entrepreneurial skills: A study of Tuscan and Welsh farmers. Journal of Rural Studies, 26(2), 116-129. https://doi. org/10.1016/j.jrurstud.2009.09.002

Read, S., Sarasvathy, S., Dew, N., \& Wiltbank, R. (2017). Effectual entrepreneurship (2. ${ }^{\text {a Ed). }}$ Routledge.

Sanchez i Peris, F. J., \& Ros Ros, C. (2014). Development of entrepreneurial competence through practicum in pedagogy degree. Procedia: Social and Behavioral Sciences, 139, 116-122. https://doi.org/10.1016/j. sbspro.2014.08.038

Schelfhout, W., Bruggeman, K., \& De Maeyer, S. (2016). Evaluation of entrepreneurial competence through scaled behavioural indicators: Validation of an instrument. Studies in Educational Evaluation, 51, 29-41. https:// doi.org/10.1016/j.stueduc.2016.09.001

Seuneke, P., Lans, T., \& Wiskerke, J. S. C. (2013). Moving beyond entrepreneurial skills: Key factors driving entrepreneurial learning in multifunctional agriculture. Journal of Rural Studies, 32, 208-219. https://doi. org/10.1016/j.jrurstud.2013.06.001

Strauti, G., Dumitrache, V. -M., \& Taucean, I. M. (2018). Entrepreneurial competences in economical engineering curriculum in Romania. Procedia: Social and Behavioral Sciences, (238), 737-742. https://doi. org/10.1016/j.sbspro.2018.04.057

Usman, A. S., \& Tasmin, R. (2015). Entrepreneurial skills development strategies through the mandatory students' industrial work experience scheme in Nigeria. Procedia: Social and Behavioral Sciences, 204, 254-258.

Zambrano, J., \& Lasio, V. (2019). Jóvenes emprendedores en Ecuador 2012-2017. GEM; ESPAE.

Zamora-Boza, C. S. (2018). La importancia del emprendimiento en la economía: el caso de Ecuador. Espacios, 39(7), 15. https:// bit.ly/3kbHXql 